\title{
Depth and Duration of Flooding Affect Growth, Yield, and Mineral Nutrition of Subirrigated Bell Pepper
}

\author{
Juana C. García-Santiago, Luis A. Valdez-Aguilar' ${ }^{1}$, \\ and Armando Hernández-Pérez \\ Departamento de Horticultura, Universidad Autónoma Agraria Antonio \\ Narro, Calzada Antonio Narro 1923, Buenavista, Saltillo, Coahuila, \\ México 25315
}

\section{Andrew D. Cartmill}

School of Agriculture, University of Wisconsin-Platteville, 1 University Plaza, Platteville, WI 53818

\section{Jesús Valenzuela-García \\ Departamento de Maquinaria Agrícola, Universidad Autónoma Agraria Antonio Narro, Calzada Antonio Narro 1923, Buenavista, Saltillo, Coahuila, México 25315}

Additional index words. closed irrigation systems, drip fertigation, vegetable crops, greenhouse crops, sustainable production

\begin{abstract}
In containerized crop production, subirrigation is an attractive solution to reduce excessive water runoff and nutrient loss. However, this irrigation method is mainly used for the cultivation of containerized ornamental plants, with limited research on the cultivation of vegetable species. In the present study, we assessed the feasibility of using a subirrigation system on growth, yield, and nutrient status of bell pepper plants (Capsicum annuum L.) grown in 30-cm-tall (13-L) containers by measuring the effects of flooding depth $(10$ and $15 \mathrm{~cm})$ and duration $(20$ and 30 minutes) and compared with drip-fertigated plants. Subirrigated bell pepper plants exhibited a fruit number and yield comparable to those of drip-fertigated plants when the solution depth was held at $15 \mathrm{~cm}$ for 30 minutes. There was a substantial increase in the electrical conductivity (EC) in the medium top layers for all subirrigated plants, but this was up to $50 \%$ lower when plants were irrigated/fertigated to a $15-\mathrm{cm}$ depth for 30 minutes. The higher yield of subirrigated plants flooded to a depth of $15 \mathrm{~cm}$ for 30 minutes was associated with a decrease in Ca concentration in the plant tissue $(-16 \%)$, probably due to a dilution effect associated with the higher biomass produced by these plants. The higher nutrient use efficiency (NUE) attributed to subirrigation systems is not only due to nutrient accumulation in the growing medium, but also to a higher uptake by the plants, as compared with drip-fertigated plants, as subirrigated plants with flooding depth and duration of 15 minutes and $30 \mathrm{~cm}$ contained $47 \%$ higher $\mathrm{N}, 44 \% \mathrm{P}, 44 \% \mathrm{~K}, 17 \% \mathrm{Ca}, 60 \% \mathrm{Mg}$, and $76 \% \mathrm{~S}$. Subirrigation of bell pepper plants is a reliable and feasible irrigation system provided flooding depth and duration are considered.
\end{abstract}

Water quantity and quality are major issues for food production. About three billion people are predicted to live in waterstressed or water-scarce environments by 2025 (Hanjra and Qureshi, 2010). Agricultural crop production systems are one of the largest consumers of water (Frija et al., 2009 ), accounting for nearly $80 \%$ of total global water use (Molden et al., 2007). The imperative need to provide food for a growing global population has resulted in increased interest in production systems that maximize water use and plant yield and quality. In

Received for publication 23 Sept. 2016. Accepted for publication 9 Nov. 2016.

1Corresponding author. E-mail: luisalonso.valdez@, uaaan.mx. protected agriculture, greenhouse-grown, soil-cultivated plants may produce high quality and yields; however, due to current irrigation practices, and subsequent runoff and infiltration, the water use efficiency (WUE) may be low (Putra and Yuliando, 2015), which may pose a threat to the environment. Greenhouse production systems have been suggested to be highly correlated with WUE (Frija et al., 2009), as similar yields have been achieved using 50\% to $100 \%$ less water when plants are cultivated using soilless media systems, when compared with "conventional" soil-grown plants (Putra and Yuliando, 2015)

Closed irrigation systems are of particular interest when compared with conventional open irrigation systems as they have been demonstrated to reduce nutrient loss and increase WUE and NUE in greenhouse crop production systems (Ahmed et al., 2000; Putra and Yuliando, 2015; Rouphael and Colla, 2005; Rouphael et al., 2004; Siddiqi et al., 1998; van Os, 1999). Among closed irrigation systems, subirrigation with nutrient and water recirculation is an excellent method to enhance plant production, quality, yield, and potentially the profitability of important cultivated plants (Cardarelli et al., 2010; Fascella and Rouphael, 2015; Rouphael et al., 2006; Santamaria et al., 2003; Uva et al., 2001).

Nonetheless, subirrigation of greenhouse crops is mainly used for the cultivation of containerized ornamental plants. It has been demonstrated that subirrigated ornamental plants have increased growth, and decreased water (van Os, 1999) and nutrient use (Blessington-Haley and Reed, 2004; Zheng et al., 2004). However, there is limited information available on using subirrigation systems for the production of vegetable species (Santamaria et al., 2003).

Subirrigation systems may enhance vegetable crop production; however, vegetable crops may have a longer cultivation time, higher growth rate, and higher nutrient and water demands, when compared with containerized ornamental plants (Rouphael and Colla, 2005; Santamaria et al., 2003). Successful subirrigation of vegetable crops may need the use of containers of larger volume due to the higher biomass and longer cultivation period associated with these crops when compared with ornamental species. Therefore, irrigation solution depth and duration of flooding have to be determined to achieve optimum wetting of the substrate and nutrient distribution as they depend on the medium and container size used. The objective of the present study was to assess the feasibility of using a subirrigation system in the production of containerized bell pepper plants by measuring the effects of flooding depth and duration on growth, yield, and mineral composition.

\section{Materials and Methods}

Cultural conditions and plant material. The study was conducted in a greenhouse in Saltillo, Coahuila, México $\left(25^{\circ} 23^{\prime} 42^{\prime \prime} \mathrm{N}\right.$ lat., $100^{\circ} 59^{\prime} 57^{\prime \prime} \mathrm{W}$ long., $1743 \mathrm{~m}$ above sea level). The mean maximum and minimum temperature for the study was 30 and $11^{\circ} \mathrm{C}$, respectively (average $18^{\circ} \mathrm{C}$ ). Mean maximum and minimum relative humidity were $95 \%$ and $40 \%$, respectively (average $77 \%$ ), and mean photosynthetically active radiation measured at solar noon was $306 \mu \mathrm{mol} \cdot \mathrm{m}^{-2} \cdot \mathrm{s}^{-1}$.

Bell pepper plants cv. Top 141 were planted on 12 Aug. 2014 into 13-L black polyethylene containers filled with a mixture of sphagnum moss, coconut fiber, and perlite $(40 \%, 40 \%, 20 \% \mathrm{v} / \mathrm{v})$ to a height of $30 \mathrm{~cm}$. Initial medium $\mathrm{pH}$ and $\mathrm{EC}$ were 6.4 and 1.1 $\mathrm{dS} \cdot \mathrm{m}^{-1}$, respectively.

Nutrient solution. Nutrient solution for both subirrigated and drip-fertigated plants 
was formulated according to Steiner's (1961) formulation, including macronutrients (meq. $\mathrm{L}^{-1}$ ): $12 \mathrm{NO}_{3}{ }^{-}, 1 \mathrm{H}_{2} \mathrm{PO}_{4}^{-}, 7 \mathrm{~K}, 4 \mathrm{Mg}$, and $2 \mathrm{SO}_{4}{ }^{2-}$ and micronutrients $\left(\mathrm{mg} \cdot \mathrm{L}^{-1}\right)$ : 5.3 Fe, 0.4 Zn, 2.6 Mn, 0.5 Cu, 0.2 B, and 0.2 Mo.

Subirrigation system and treatments. There were four subirrigation treatments, consisting of two flooding depths (10 or $15 \mathrm{~cm}$ ) and two flooding durations (20 or $30 \mathrm{~min}$ ) in which the containers remained standing in the nutrient solution. Subirrigation started when the growing medium registered a moisture tension of $1 \mathrm{kPa}$. In subirrigated treatments, two one-plant containers were placed in rigid plastic trays/ troughs $(69 \times 39 \times 16 \mathrm{~cm}$; length, width, and height). The control treatment consisted of plants irrigated through a drip fertigation system on which each container had four emitters dispensing a total of $4 \mathrm{~L}$ of nutrient solution per hour; plants were irrigated as needed with enough solution to achieve a $25 \%$ leaching fraction. The nutrient solution, in both, subirrigated and dripfertigated plants, was checked and adjusted as required for $\mathrm{pH}$ and $\mathrm{EC}$ before the next fertigation event. The nutrient solution $\mathrm{pH}$ was adjusted to $6.0 \pm 0.1$ with $\mathrm{H}_{2} \mathrm{SO}_{4}$ $(0.1 \mathrm{~N})$ and EC was maintained at 2.3 $\mathrm{dS} \cdot \mathrm{m}^{-1}$ for experiment duration by replacing the evapotranspirated water. In subirrigated plants, the unabsorbed solution was drained back into a $200-\mathrm{L}$ storage tank and renewed every $15 \mathrm{~d}$.

Plant growth and mineral composition. The experiment was ended $165 \mathrm{~d}$ after transplanting. Fruits were harvested throughout the experiment, starting $120 \mathrm{~d}$ after transplanting. Fruit was considered ready for harvest when $80 \%$ of the pericarp had obtained a red color. At experiment termination, total fruit number and yield were determined, and plants were harvested and washed twice in distilled water, separated into roots, stems and leaves, along with all the harvested fruits, and dried in an oven at $70{ }^{\circ} \mathrm{C}$ for $72 \mathrm{~h}$ for dry weight calculation.

Dry plant tissues [root, shoot (stem and leaves), and all the harvested fruits] were ground in a Wiley mill to pass a 20-mesh sieve (Thomas-Wiley Mill Co., Philadelphia, PA) and a tissue mineral analysis was conducted, including total $\mathrm{N}$ concentration with Kjeldhal's procedure (Bremner, 1996), while $\mathrm{P}, \mathrm{K}, \mathrm{Ca}, \mathrm{Mg}$, and $\mathrm{S}$ were determined with inductively coupled plasma emission spectrometer (ICP-AES, model Liberty; VARIAN, Santa Clara, CA) in ground tissues digested in a $2: 1$ mixture of $\mathrm{H}_{2} \mathrm{SO}_{4}$ : $\mathrm{HClO}_{4}$ and $2 \mathrm{~mL}$ of $30 \% \mathrm{H}_{2} \mathrm{O}_{2}$ for $\mathrm{P}, \mathrm{K}, \mathrm{Ca}$, and $\mathrm{Mg}$, whereas $\mathrm{S}$ was determined in ground tissues digested in a mixture of $\mathrm{HNO}_{3}: \mathrm{HClO}_{4}$ (Soltanpour et al., 1996). Macronutrients accumulated in the root, shoot, fruit, and in the entire plant were calculated considering their concentration and the dry weight of each plant part.

At harvest, the root ball was carefully separated into four layers; from bottom to the top, the layers were $0-7,7-14,14-21$, and $21-28 \mathrm{~cm}$. Samples of the growing medium from each layer were collected and thoroughly mixed with distilled water in a 1:2 proportion $(30 \mathrm{~mL}$ of growing medium: $60 \mathrm{~mL}$ of water) allowed to sit for $60 \mathrm{~min}$ and then filtered. The filtrate pH (LAQUA twin B-712; Horiba Ltd., Kyoto, Japan), EC (LAQUA twin B-771; Horiba Ltd., Kyoto, Japan), $\mathrm{NO}_{3}{ }^{-}$(LAQUA twin B-741; Horiba Ltd., Kyoto, Japan), K (LAQUA twin B-731; Horiba Ltd., Kyoto, Japan), and $\mathrm{Ca}$ (LAQUA twin B-751; Horiba Ltd., Kyoto, Japan) concentrations were determined.

Statistical design. The experimental unit consisted of two plants (20 cm apart), each in an individual container. Four replicates of each experimental unit were distributed in a completely randomized block design. Data were analyzed with analysis of variance and Duncan's multiple mean comparison test $(P \leq 0.05)$ using SAS v. 9.2; the data for the chemical properties of the growing medium layers were analyzed as a factorial on which fertigation treatments and medium layers were the factors with four levels each.

\section{Results and Discussion}

Bell pepper plants grown in flooded trays/ troughs to a depth of $15 \mathrm{~cm}$ for $30 \mathrm{~min}$ produced a number and yield of fruits similar to those of drip-fertigated plants (Table 1). In addition, these subirrigated plants exhibited increased biomass production as they had a higher root, stem, leaf, and total dry weight when compared with drip-fertigated plants (Table 2). All the other flooding depths and durations assessed resulted in a lower number of fruits and yield, as well as decreased

dry weight. The results observed in the present study suggest that subirrigation is a feasible irrigation method for vegetable species as long as important aspects such as flooding depth and duration are considered. In contrast to our results, Santamaria et al. (2003) and Bouchaaba et al. (2015) indicate that, when compared with drip-fertigated plants, the yield of subirrigated cherry tomato (Lycopersicon esculentum var. cerasiforme Alef.) and green beans (Phaseolus vulgaris L.) decreased by $20 \%$ and $33 \%$, respectively, whereas Scholberg and Locascio (1999) reported a decrease in the size and number of fruits in tomato (Lycopersicon esculentum Mill.).

The decrease in yield, growth, and biomass that has been reported for subirrigated plants has been ascribed to the increase in the EC of the top layer of the growing medium and to an uneven distribution of moisture throughout the medium profile (Bouchaaba et al., 2015; Cox, 2001; Montesano et al., 2010; Nemali and van Iersel, 2004). In the present study, subirrigation also resulted in higher EC in the growing medium when compared with that of drip-fertigated plants (Table 3). However, the effect on EC was more pronounced in the $21-28 \mathrm{~cm}$ top layer of the growing medium as in subirrigated plants it ranged from 5.0 to $7.5 \mathrm{dS} \cdot \mathrm{m}^{-1}$, whereas in the drip-fertigated plants, it was $\approx 2.0 \mathrm{dS} \cdot \mathrm{m}^{-1}$ (Fig. 1A). The higher EC in the top layers that is typically observed in subirrigated containerized plants is due to the upward migration of salts along with the capillary movement of water (Cox, 2001; Incrocci et al., 2006; Matysiak and Bielenin, 2005; Montesano et al., 2010; Rouphael et al., 2008; Whitcher et al., 2005; Zheng et al., 2004). The concentration, root uptake rate, and mass flow of

Table 1. Effect of the flooding depth and duration on fruit number and yield of subirrigated and dripfertigated greenhouse bell pepper in containers.

\begin{tabular}{|c|c|c|c|c|}
\hline \multirow[b]{2}{*}{ Irrigation method } & \multicolumn{2}{|c|}{ Flooding } & \multirow[b]{2}{*}{ No. of fruits } & \multirow[b]{2}{*}{ Fruit yield (g/plant) } \\
\hline & Depth $(\mathrm{cm})$ & Duration (min) & & \\
\hline \multirow[t]{4}{*}{ Subirrigation } & 10 & 20 & $4.15 \mathrm{~b}$ & $550 \mathrm{c}$ \\
\hline & & 30 & $3.33 \mathrm{~b}$ & $540 \mathrm{c}$ \\
\hline & 15 & 20 & $5.00 \mathrm{a}$ & $712 \mathrm{~b}$ \\
\hline & & 30 & $5.25 \mathrm{a}$ & $857 \mathrm{a}$ \\
\hline \multirow[t]{2}{*}{ Drip fertigation } & & & $5.38 \mathrm{a}$ & $790 \mathrm{ab}$ \\
\hline & & $P$ value & $\leq 0.001$ & $\leq 0.001$ \\
\hline
\end{tabular}

Treatments with different letters were significantly different according to Duncan's multiple comparison test $(P \leq 0.05)$.

Table 2. Effect of the flooding depth and duration on root, stem, leaf, and total dry mass of subirrigated and drip-fertigated greenhouse bell pepper in containers.

\begin{tabular}{|c|c|c|c|c|c|c|}
\hline \multirow[b]{2}{*}{ Irrigation method } & \multicolumn{2}{|c|}{ Flooding } & Roots & Stems & Leaves & Total \\
\hline & Depth (cm) & Duration (min) & \multicolumn{4}{|c|}{ (g/plant) } \\
\hline \multirow[t]{4}{*}{ Subirrigation } & 10 & 20 & $17.5 \mathrm{~b}$ & $17.2 \mathrm{c}$ & $13.4 \mathrm{e}$ & $48.2 \mathrm{e}$ \\
\hline & & 30 & $14.8 \mathrm{c}$ & $22.7 \mathrm{~b}$ & $17.8 \mathrm{~d}$ & $55.3 \mathrm{~d}$ \\
\hline & 15 & 20 & $23.2 \mathrm{a}$ & $31.3 \mathrm{a}$ & $26.7 \mathrm{~b}$ & $81.2 \mathrm{~b}$ \\
\hline & & 30 & $23.8 \mathrm{a}$ & $34.8 \mathrm{a}$ & $29.7 \mathrm{a}$ & $88.3 \mathrm{a}$ \\
\hline \multirow[t]{2}{*}{ Drip fertigation } & & & $19.6 \mathrm{~b}$ & $25.0 \mathrm{~b}$ & $20.6 \mathrm{c}$ & $65.1 \mathrm{c}$ \\
\hline & & $P$ value & $\leq 0.001$ & $\leq 0.001$ & $\leq 0.001$ & $\leq 0.001$ \\
\hline
\end{tabular}

Treatments with different letters were significantly different according to Duncan's multiple comparison test $(P \leq 0.05)$. 
Table 3. Effect of flooding depth and flooding duration and growing medium layer (from bottom to top) in subirrigated and drip-fertigated greenhouse bell pepper in containers on $\mathrm{pH}$, electrical conductivity (EC), and calcium $(\mathrm{Ca})$, potassium $(\mathrm{K})$, and nitrate $\left(\mathrm{NO}_{3}{ }^{-}\right)$concentrations in the growing medium at experiment termination.

\begin{tabular}{|c|c|c|c|c|c|c|c|}
\hline Irrigation method & Flooding depth $(\mathrm{cm})$ & Flooding duration (min) & $\mathrm{pH}$ & $\mathrm{EC}\left(\mathrm{dS} \cdot \mathrm{m}^{-1}\right)$ & $\mathrm{Ca}(\mathrm{ppm})$ & $\mathrm{K}(\mathrm{ppm})$ & $\mathrm{NO}_{3}{ }^{-}(\mathrm{ppm})$ \\
\hline \multirow[t]{4}{*}{ Subirrigation } & \multirow[t]{2}{*}{10} & 20 & 4.71 & $2.51 \mathrm{a}$ & $39.5 \mathrm{~b}$ & $306 \mathrm{c}$ & $78.7 \mathrm{~b}$ \\
\hline & & 30 & 4.88 & $2.49 \mathrm{a}$ & $28.5 \mathrm{c}$ & $280 \mathrm{~cd}$ & $74.1 \mathrm{~b}$ \\
\hline & \multirow[t]{2}{*}{15} & 20 & 4.72 & $2.12 \mathrm{~b}$ & $30.8 \mathrm{c}$ & $404 \mathrm{a}$ & $80.4 \mathrm{~b}$ \\
\hline & & 30 & 4.72 & $1.96 \mathrm{c}$ & $29.1 \mathrm{c}$ & $362 \mathrm{~b}$ & $77.4 \mathrm{~b}$ \\
\hline \multicolumn{3}{|l|}{ Drip fertigation } & 4.87 & $1.14 \mathrm{~d}$ & $91.9 \mathrm{a}$ & $253 \mathrm{~d}$ & $97.1 \mathrm{a}$ \\
\hline \multirow{4}{*}{\multicolumn{2}{|c|}{ Growing medium layer $(\mathrm{cm})$}} & $0-7$ & $6.16 \mathrm{a}$ & $0.73 \mathrm{~d}$ & $39.3 \mathrm{~b}$ & $208 \mathrm{~d}$ & $145 \mathrm{a}$ \\
\hline & & $7-14$ & $5.69 \mathrm{~b}$ & $0.84 \mathrm{c}$ & $40.1 \mathrm{~b}$ & $256 \mathrm{c}$ & $97 \mathrm{~b}$ \\
\hline & & $14-21$ & $4.49 \mathrm{c}$ & $1.23 \mathrm{~b}$ & $43.4 \mathrm{~b}$ & $308 \mathrm{~b}$ & $52 \mathrm{c}$ \\
\hline & & $21-28$ & $2.77 \mathrm{~d}$ & $5.37 \mathrm{a}$ & $53.0 \mathrm{a}$ & $511 \mathrm{a}$ & $32 \mathrm{~d}$ \\
\hline \multirow{3}{*}{\multicolumn{2}{|c|}{$P$ value }} & Irrigation method & NS & $\leq 0.001$ & $\leq 0.001$ & $\leq 0.001$ & $\leq 0.001$ \\
\hline & & Medium layer & $\leq 0.001$ & $\leq 0.001$ & $\leq 0.001$ & $\leq 0.001$ & $\leq 0.001$ \\
\hline & & Interaction & $\leq 0.001$ & $\leq 0.001$ & $\leq 0.001$ & $\leq 0.001$ & $\leq 0.001$ \\
\hline
\end{tabular}

Treatments with different letters were significantly different according to Duncan's multiple comparison test $(P \leq 0.05)$.

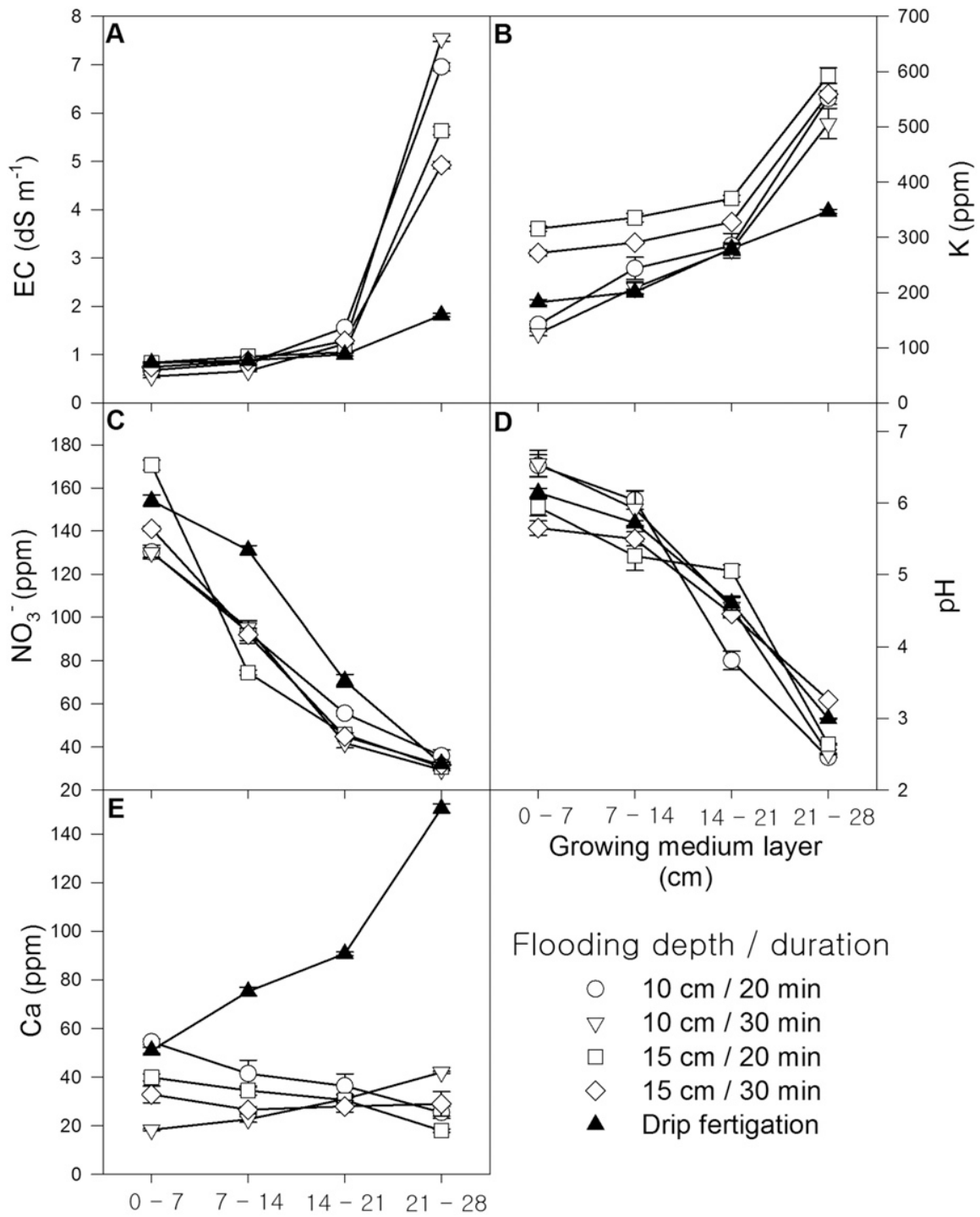

Fig. 1. Electrical conductivity (EC), $\mathrm{pH}$, and concentration of potassium $(\mathrm{K})$, nitrate $\left(\mathrm{NO}_{3}{ }^{-}\right)$, and calcium (Ca) at experiment termination in four medium layers as affected by flooding depth $(\mathrm{cm})$ and duration (min).

nutrients in the medium, as well as the evapotranspiration rate, are other factors that cause a higher EC in the top layer (Incrocci et al., 2006; Kang and van Iersel, 2001; Reed, 1996; Rouphael and Colla, of $15 \mathrm{~cm}$ for $30 \mathrm{~min}$, suggesting that flooding depth and duration are critical issues to avoid excessive salinization of the medium. This lower media EC when plants were irrigated to a depth of $15 \mathrm{~cm}$ for $30 \mathrm{~min}$ may be due to a more even distribution of nutrient solution throughout the media, which in turn may enhance root growth in the top layers.

Potassium in the growing medium tended to increase in the top layers of the root ball profile regardless of the irrigation system (Table 3; Fig. 1B); however, the increase was greatest in the $21-28 \mathrm{~cm}$ layer of subirrigated plants. Medium $\mathrm{NO}_{3}{ }^{-}$concentration (Fig. 1C) and $\mathrm{pH}$ (Fig. 1D) exhibited a contrasting response as both tended to decrease in the top layers, regardless of the irrigation method. Calcium concentration was very consistent throughout the growing medium layers in subirrigated plants as it ranged from 20 to $60 \mathrm{ppm}$ (Fig. 1E); however, it increased in the upper layers, from the $7-14$ to the $21-28 \mathrm{~cm}$ layer, in drip-fertigated plants. Zheng et al. (2004) suggested that the higher EC in the top third of the medium of subirrigated plants was associated with a higher concentration of $\mathrm{NO}_{3}^{-}, \mathrm{HPO}_{4}{ }^{2-}, \mathrm{H}_{2} \mathrm{PO}_{4}^{-}, \mathrm{K}$, $\mathrm{Mg}$, and $\mathrm{Ca}$. However, in our study, the higher EC observed in the 21-28 cm layers was associated with an accumulation of $\mathrm{K}$, which was $40 \%$ to $71 \%$ higher in the medium of subirrigated plants compared with that of the top layer of drip-fertigated plants. Blessington-Haley and Reed (2004) reported similar results as EC and $\mathrm{K}$ concentration in the medium exhibited the same tendency. The increase in Ca concentration in the top layers of the growing medium observed in drip-fertigated plants, which is in contrast to the negligible effect observed in subirrigated plants, may be due to a lower uptake rate of this nutrient as roots usually exhibit poor growth in the top layers of subirrigated plants (Kent and Reed, 1996).

Nitrate tended to accumulate in the bottom layers of the medium, regardless of the irrigation method. This is in contrast to reports by Zheng et al. (2004) and by Kent and Reed (1996), which indicate that the concentration of $\mathrm{NO}_{3}{ }^{-}$is reflective of 
the higher EC in the medium profile. The contrasting results may be due to the different physical properties of the medium used between the respective studies and to the leaching fraction used for the dripfertigated plants.

The higher yield of subirrigated plants flooded to a depth of $15 \mathrm{~cm}$ for $30 \mathrm{~min}$ was associated with a decrease in total plant $\mathrm{Ca}$ concentration, which occurred primarily in the shoot and roots, but not in the fruit (Table 4). This may be due to a dilution effect associated with the higher biomass produced by these plants, as suggested by the higher total content of $\mathrm{Ca}$ in subirrigated plants when compared with drip-fertigated plants. Phosphorus concentration was affected in the root and in the whole plant with no clear trend as to the effect of irrigation method or flooding depth or duration (Table 4).

Total plant $\mathrm{N}, \mathrm{P}, \mathrm{Mg}$, and $\mathrm{S}$ contents were higher in subirrigated plants when flooded to $15-\mathrm{cm}$ depth for 20 to $30 \mathrm{~min}$ (Table 4; Fig. 2). Potassium and Ca content were also higher when plants were flooded to $15-\mathrm{cm}$ depth for $30 \mathrm{~min}$ (Fig. 2). However, $\mathrm{Ca}$ and $\mathrm{K}$ contents were lower in subirrigated plants flooded to $10-\mathrm{cm}$ depth for 20 to $30 \mathrm{~min}$ (Fig. 2). In addition, this lower solution depth $(10 \mathrm{~cm})$ was also associated with a shift in nutrient allocation as $\mathrm{Ca}$ tended to accumulate in the roots, whereas $\mathrm{K}$ accumulated in the shoots. In general, flooding of plants in solutions of 15-cm depth for $30 \mathrm{~min}$ had limited effect on nutrient allocation when compared with the drip-fertigated plants.

Subirrigated plants, regardless of flooding depth and duration, showed higher $\mathrm{K}$ concentration in the fruit tissues than dripfertigated plants, which may be due to the higher $\mathrm{K}$ accumulated in the growing medium (Table 4). However, shoot $\mathrm{Mg}$ and $\mathrm{S}$ concentration in subirrigated plants increased due to a higher allocation to the shoots when flooded to $15-\mathrm{cm}$ depth for 30 min (Table 4).

The present study showed that the higher NUE attributed to subirrigation systems in similar studies (Ahmed et al., 2000; Putra and Yuliando, 2015; Rouphael and Colla, 2005; Rouphael et al., 2004; Siddiqi et al., 1998; van Os, 1999) might not be only due to their "even/balanced" accumulation in the growing medium by capillary action, but also to a higher uptake by plants. This is demonstrated by the increased total content of all the macronutrients observed in subirrigated plants with flooding depths of $15 \mathrm{~cm}$ for $30 \mathrm{~min}$ when compared with drip-fertigated plants. These results are in contrast to reports by Rouphael and Colla (2005) in that subirrigated zucchini plants (Cucurbita pepo L.) had decreased total $\mathrm{N}, \mathrm{P}, \mathrm{K}, \mathrm{Ca}$, and $\mathrm{Mg}$ content. In our study, the higher accumulation of macronutrients was associated with flooding duration as this trend was also observed for the total content of N, P, $\mathrm{Mg}$, and $\mathrm{S}$ in plants flooded to a $20-\mathrm{cm}$ depth, suggesting that plants flooded with
$10 \mathrm{~cm}$ were not able to take advantage of the higher availability of nutrients in the medium.

The lower total content of macronutrients in plants flooded to depths of $10 \mathrm{~cm}$ may be due to the higher EC ( 7.0 to $7.6 \mathrm{dS} \cdot \mathrm{m}^{-1}$ ) observed in the 21-28 $\mathrm{cm}$ medium layer when compared with the EC ( 5 to $5.7 \mathrm{dS} \cdot \mathrm{m}^{-1}$ ) of plants flooded to depths of $15 \mathrm{~cm}$. Subirrigation also affected the allocation of nutrients as, from the total content, higher $\mathrm{K}$ and $\mathrm{P}$ were diverted to the shoot and fruits; $\mathrm{Mg}$ and $\mathrm{S}$ allocation to the shoot in plants flooded to $15-\mathrm{cm}$ depth for $30 \mathrm{~min}$ was at the expense of the roots.

In conclusion, subirrigation is an effective and feasible irrigation system for the production of bell pepper plants if flooding depth and duration are controlled. Fruit yield may be as high as that of drip-fertigated plants when the nutrient solution depth is $15 \mathrm{~cm}$ and it is maintained for $30 \mathrm{~min}$. This response was associated with a higher nutrient accumulation, lower EC of the top layers of the growing medium, unaffected $\mathrm{N}$ and $\mathrm{P}$ plant tissue concentration, and increased $\mathrm{Mg}$ and $\mathrm{S}$ plant tissue concentration. Nonetheless, more research is required as to the effect of flooding depth and duration since the results observed were obtained in very specific growing conditions, and the physical properties of the growing medium used in the study directly impact capillary movement of water and water retention.

Table 4. Effect of flooding depth and flooding duration on nitrogen $(\mathrm{N})$, phosphorus $(\mathrm{P})$, potassium $(\mathrm{K})$, calcium $(\mathrm{Ca})$, magnesium $(\mathrm{Mg})$, and sulfur $(\mathrm{S})$ concentration in plant parts of subirrigated and drip-fertigated greenhouse bell pepper in containers at experiment termination.

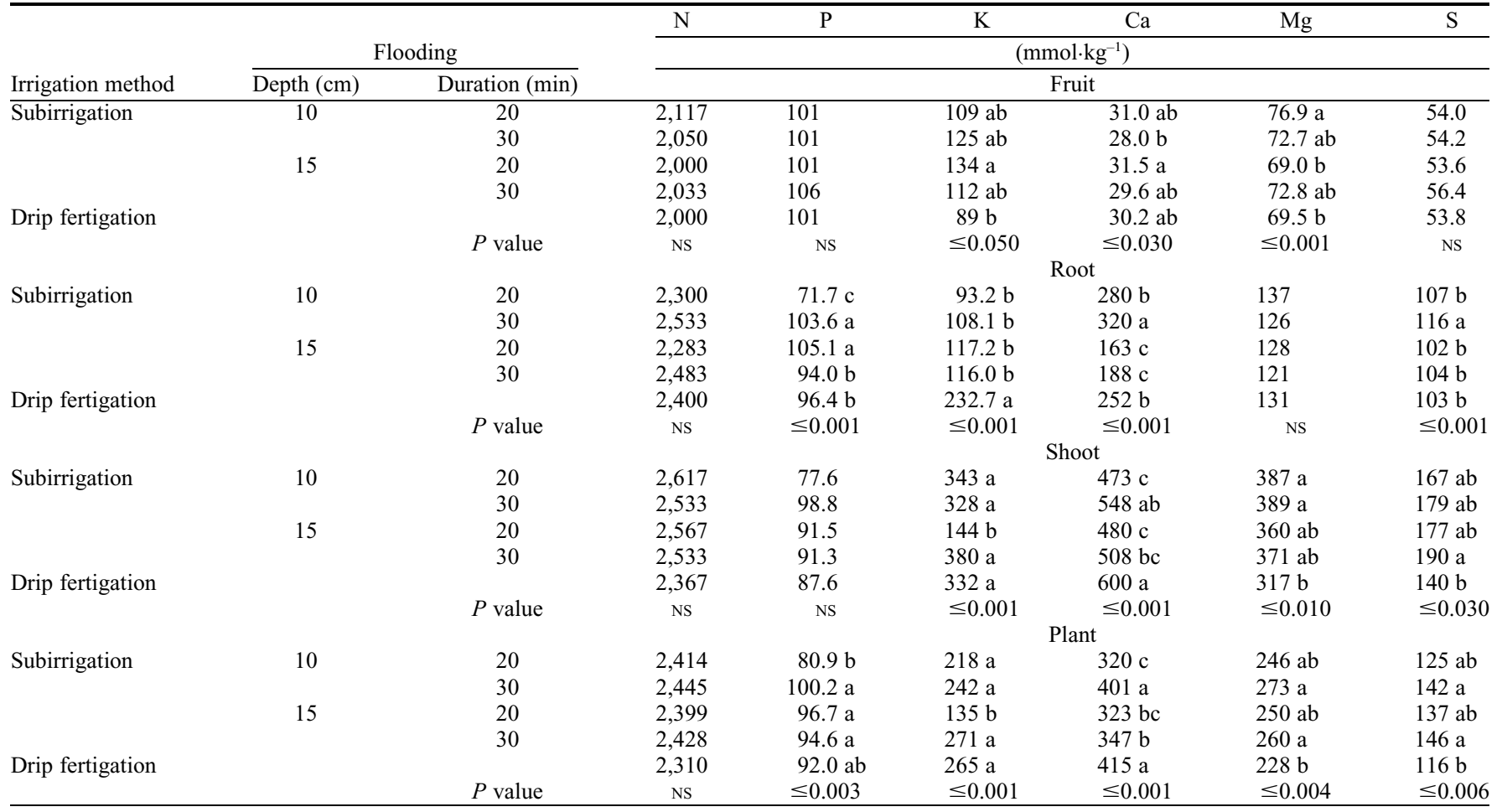

Treatments with different letters were significantly different according to Duncan's multiple comparison test $(P \leq 0.05)$. 


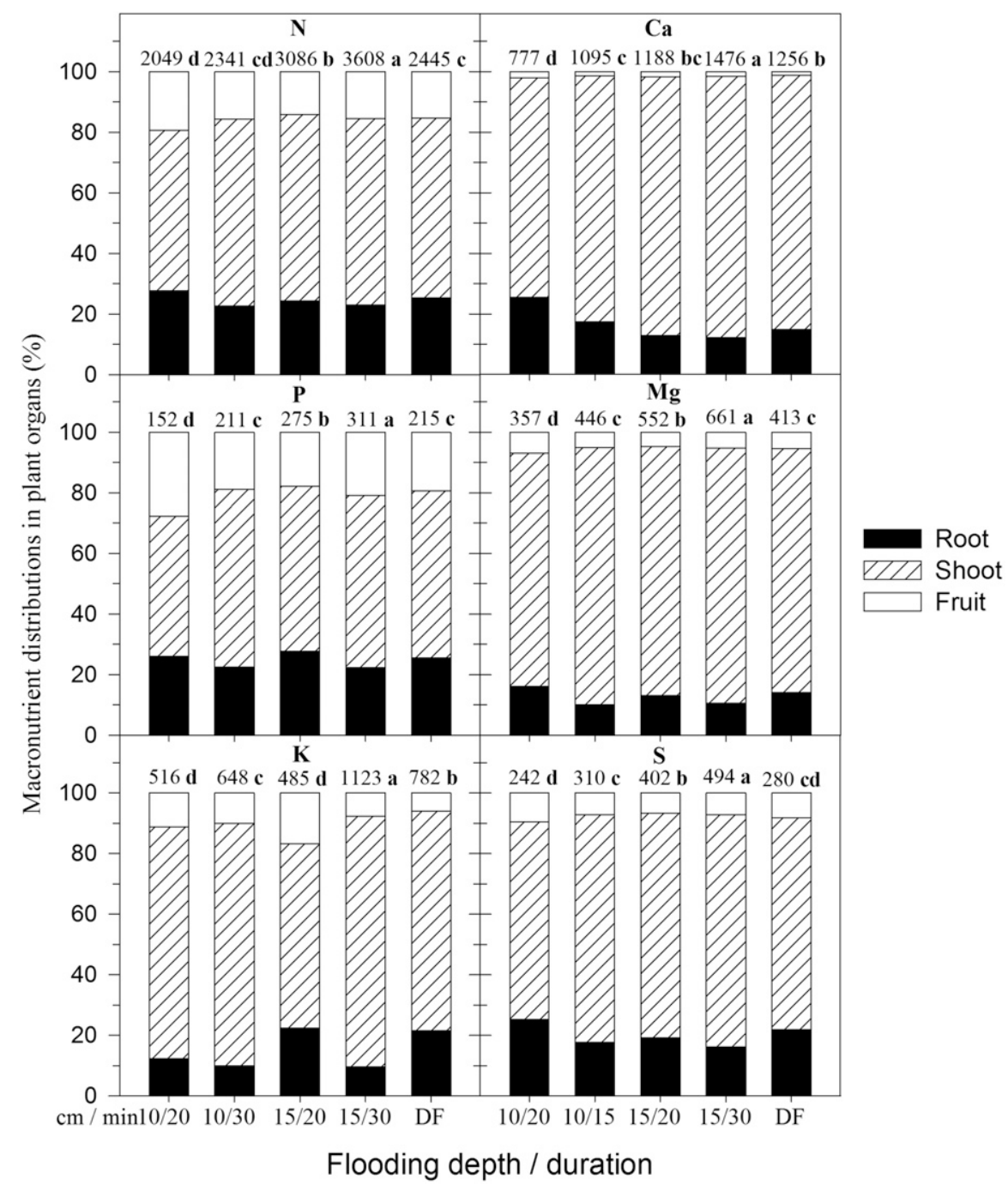

Fig. 2. Total tissue content (mg/plant) of nitrogen $(\mathrm{N})$, calcium $(\mathrm{Ca})$, phosphorus $(\mathrm{P})$, magnesium $(\mathrm{Mg})$, potassium (K), and sulfur (S) (figures at the top of each column) and allocation in organs of bell pepper plants as affected by flooding depth $(\mathrm{cm})$ and duration $(\mathrm{min})$. Means followed by different letters are significantly different according to Duncan's multiple comparison test $(P \leq 0.05)$. DF $=$ drip fertigation.

\section{Literature Cited}

Ahmed, A.K., G.C. Cresswell, and A.M. Haigh. 2000. Comparison of sub-irrigation and overhead irrigation of tomato and lettuce seedlings. J. Hort. Sci. Biotechnol. 75:350-354.

Blessington-Haley, T. and D.W. Reed. 2004. Optimum potassium concentrations in recirculating subirrigation for selected greenhouse crops. HortScience 39:1441-1444.

Bouchaaba, Z., P. Santamaria, R. Choukr-Allah, N. Lamaddalena, and F.F. Montesano. 2015. Open-cycle drip vs closed-cycle subirrigation: Effects on growth and yield of greenhouse soilless green bean. Sci. Hort. 182:77-85.

Bremner, J.M. 1996. Total nitrogen, p. 1085-1086. In: D.L. Sparks (ed.). Methods of soil analysis. Part 3. Chemical methods. Soil Science Society of America, Madison, WI.

Cardarelli, M., Y. Rouphael, E. Rea, A. Salerno, and G. Colla. 2010. Nutrient solution concentration and growing season affect growth and quality of potted petunia in a recirculating subirrigation and drip-irrigation system. J. Food. Agr. Environ. 8:312-320.

Cox, D.A. 2001. Growth, nutrient content, and growth medium electrical conductivity of poinsettia gation system. J. Amer. Soc. Hort. Sci. 121:816-819.

Matysiak, B. and M. Bielenin. 2005. Effect of nutrient solution composition on growth, flowering, nutrient status and cold hardiness of Rhododendron yakushimanum grown on ebb-and-flow benches. Eur. J. Hort. Sci. 70:35-42.

Molden, D., T.Y. Oweis, S. Pasquale, J.W. Kijne, M.A. Hanjra, P.S. Bindraban, B.A.M. Bouman, S. Cook, O. Erenstein, A. Hachum, J. Hoogeveen, H. Mahoo, V. Nangia, D. Peden, A. Sikka, P. Silva, H. Turral, A. Upadhyaya, and S. Zwart. 2007. Pathways for increasing agricultural water productivity, p. 279-310. In: D. Molden (ed.). Water for food, water for life: A comprehensive assessment of water management in agriculture. Earthscan, London, UK; IWMI, Colombo, Sri Lanka.

Montesano, F., A. Parente, and P. Santamaria 2010. Closed cycle subirrigation with low concentration nutrient solution can be used for soilless tomato production in saline conditions. Sci. Hort. 124:338-344.

Nemali, K.S. and M.W. van Iersel. 2004. Light intensity and fertilizer concentration: II. Optimal fertilizer solution concentration for species differing in light requirement and growth rate. HortScience 39:1293-1297.

Putra, P.A. and H. Yuliando. 2015. Soilless culture system to support water use efficiency and product quality: A review. Agr. Agr. Sci. Proc. 3:283-288.

Reed, D.W. 1996. Closed production systems for containerized crops: Recirculating subirrigation and zero-leach system, p. 221-245. In: D.W. Reed (ed.). Water, media and nutrition for greenhouse crops. Ball Publishing, Batavia, IL.

Rouphael, Y. and G. Colla. 2005. Growth, yield, fruit quality and nutrient uptake of hydroponically cultivated zucchini squash as affected by irrigation systems and growing seasons. Sci. Hort. 105:177-195.

Rouphael, Y., M. Cardarelli, E. Rea, and G. Colla. 2008. The influence of irrigation system and nutrient solution concentration on potted geranium production under various conditions of radiation and temperature. Sci. Hort. 118:328337.

Rouphael, Y., M. Cardarelli, E. Rea, A. Battistelli, and G. Colla. 2006. Comparison of the subirrigation and drip-irrigation systems for greenhouse zucchini squash production using saline and non-saline nutrient solutions. Agr. Water Mgt. 82:99-117.

Rouphael, Y., G. Colla, A. Battistelli, S. Moscatello, and E. Rea. 2004. Yield, water requirement, nutrient uptake and fruit quality of zucchini squash grown in soil and soilless culture. J. Hort. Sci. Biotechnol. 79:423-430.

Santamaria, P., G. Campanile, A. Parente, and A. Elia. 2003. Subirrigation vs. drip-irrigation: Effects on yield and quality of soilless grown cherry tomato. J. Hort. Sci. Biotechnol. 78:290296.

Scholberg, J.M.S. and S.J. Locascio. 1999. Growth response of snap bean and tomato as affected by salinity and irrigation method. HortScience 34:259-264.

Siddiqi, M.Y., H.J. Kronzucker, D.T. Britto, and A.D.M. Glass. 1998. Growth of a tomato crop at reduced nutrient concentrations as a strategy to limit eutrophication. J. Plant Nutr. 21:18791895.

Soltanpour, P.N., G.W. Johnson, S.M. Workman, J. B. Jones, and R.O. Miller. 1996. Inductively coupled plasma emission spectrometry and 
inductively coupled plasma mass spectrometry, p. 91-139. In: D.L. Sparks (ed.). Methods of soil analysis. Part 3. Chemical methods. Soil Science Society of North America, Madison, WI.

Steiner, A.A. 1961. A universal method for preparing nutrient solutions of a certain desired composition. Plant Soil 15:134-154.
Uva, W., T. Weiler, and R. Milligan. 2001. Economic analysis of adopting zero runoff subirrigation systems in greenhouse operations in the northeast and north central United States. HortScience 36:167-173.

van Os, E.A. 1999. Closed soilless growing systems: A sustainable solution for Dutch greenhouse horticulture. Water Sci. Technol. 39:105-112.
Whitcher, C.L., M.W. Kent, and D.W. Reed. 2005. Phosphorus concentration affects New Guinea impatiens and vinca in recirculating subirrigation. HortScience 40:2047-2051.

Zheng, Y., T. Graham, S. Richard, and M. Dixon. 2004. Potted gerbera production in a subirrigation system using low-concentration nutrient solutions. HortScience 39:1283-1286. 